\title{
PHYTOCHEMICAL SCREENING, TOTAL PHENOLIC CONTENT, AND ANTIOXIDANT ACTIVITY OF WATER, ETHYL ACETATE, AND N-HEXANE FRACTIONS FROM MISTLETOE MORINGA OLEIFERA LAM. (DENDROPHTHOE PENTANDRA (L.) MIQ.)
}

\author{
NIA KRISTININGRUM*, LESTYO WULANDARI, AINI ZUHRIYAH \\ Department of Pharmaceutical Chemistry, Faculty of Pharmacy, University of Jember, Jawa Timur, Indonesia. \\ Email: niakristiningrum.farmasi@unej.ac.id
}

Received: 13 February 2018, Revised and Accepted: 06 June 2018

\section{ABSTRACT}

Objective: This study was to investigate the phytochemical screening, total phenolic content (TPC), and antioxidant activity of fractions of water, ethyl acetate, and n-hexane from Dendrophthoe pentandra (L.) Miq. and mistletoe of Moringa oleifera Lam.

Methods: Simplicia extracted with 96\% ethanol using maceration method. Liquid-liquid extraction was used for fractionation with water, ethyl acetate, and n-hexane as solvent. Phytochemical screening, determination of TPC, and antioxidant activity were performed against these fractions. Antioxidant activity was determined by 2,2-diphenyl-1-picrylhydrazyl method. The TPC was measured by Folin-Ciocalteu reagent and use gallic acid $(\mathrm{GA})$ as a standard.

Results: Water fraction contains saponin and polyphenols. Ethyl acetate fraction contains alkaloids, flavonoids, saponins, terpenoids, and polyphenols. $\mathrm{N}$-hexane fraction only contains alkaloids and terpenoids. The TPC and antioxidant activity of fractions of water, ethyl acetate, and n-hexane were $9.42 \pm 1.16 \%, 21.35 \pm 1.86 \%$, and $67.40 \pm 0.82 \% \mathrm{mg} \mathrm{GA}$ equivalent/g fraction and $29.46 \mu \mathrm{g} / \mathrm{ml} \pm 0.99 \%, 7.08 \mu \mathrm{g} / \mathrm{ml} \pm 0.39 \%$, and $10.90 \mu \mathrm{g} / \mathrm{ml} \pm 1.05 \%$, respectively.

Conclusion: Fraction of ethyl acetate exhibited the highest antioxidant activity and TPC. This study showed that there were significant correlations between TPC and antioxidant activity at significance level $\mathrm{p}<0.05$.

Keywords: Mistletoe Moringa oleifera Lam., Dendrophthoe pentandra (L.) Miq., Total phenolic content, Antioxidant activity.

(c) 2018 The Authors. Published by Innovare Academic Sciences Pvt Ltd. This is an open access article under the CC BY license (http://creativecommons. org/licenses/by/4. 0/) DOI: http://dx.doi.org/10.22159/ajpcr.2018.v11i10.25271

\section{INTRODUCTION}

Free radical is naturally formed in the body through oxidation and combustion cells. Free radical is unstable because its unpaired electron so that it will react with the surrounding molecules to obtain the electron pair to become stable. This reaction will lead to oxidative stress that can cause cellular damage as well as various degenerative diseases [1]. The biological system of the body has actually produced antioxidants that can reduce the activity of free radicals whereas can also be obtained from natural and synthetic materials [2]. Natural antioxidant compounds from plants are in the form of phenolic or polyphenolic compounds. The natural antioxidants have some advantages such as being obtained easily and economically and have slight or no side effects [3].

Mistletoe is semi-parasitic plants widely spread in Indonesia. Although mistletoe can destroy the host plants, it has an ability to be medicinal plants [4]. Mistletoe is one of the plants that contain high phenolic compounds and can be a source of natural antioxidants. Since mistletoe is a semi-parasitic plant, it was suggested that their bioactivities and their secondary metabolite compounds in each type of mistletoe depend on their host. This is partly due to the acquisition of nutrients and minerals and defensive compounds of the host [5]. One of the suspected mistletoe for having high antioxidant activity is mistletoe that sticks on the Moringa oleifera tree that is Dendrophthoe pentandra (L.) Miq. D. pentandra (L.) Miq. is one of the Indonesian mistletoes species which belong to the family of Loranthaceae.

The chemical compound of the mistletoe that grows on the moringa host is also influenced by the chemical compounds found on the moringa tree as its host. Previous studies of the extraction of moringa leaf (M. oleifera
Lam.) showed high antioxidant activity with $\mathrm{IC}_{50} 1.60 \pm 0.03 \mu \mathrm{g} / \mathrm{ml}[6]$. Moringa leaf (M. oleifera Lam.) has been reported to be a rich source of carotene, vitamins, minerals, acids amino, flavonoid, and phenol compounds [7].

Several studies have shown that D. pentandra (L.) Miq. as one of mistletoe which grows in different hosts such as lobbies, cloves, ambarella, and sugar apple has antioxidant activity with $\mathrm{IC}_{50} 17.60 \mu \mathrm{g} / \mathrm{ml}, 6.40 \mu \mathrm{g} / \mathrm{ml}$, $34.10 \mu \mathrm{g} / \mathrm{ml}$, and $13.90 \mu \mathrm{g} / \mathrm{ml}$, respectively [8-10].

In this study, mistletoe leaf of M. oleifera Lam. was extracted and partitioned with the different solvent that used to evaluated phytochemical screening, antioxidant activity with 2,2-diphenyl-1picrylhydrazyl (DPPH) free radical scavenging method, and total phenol content with Folin-Ciocalteu method.

\section{MATERIALS AND METHODS}

Materials

D. pentandra (L.) Miq. leaves that were collected from around Tawangsari village, East Java, Indonesia. Ethanol 96\%, sterile distilled water, ethyl acetate, n-hexane, methanol, Vitamin C (PT. Brataco), gallic acid (GA) standard (Sigma-Aldrich), diphenylpicrilhidrazil/DPPH (Sigma-Aldrich), Folin-Ciocalteu (Merck), and sodium carbonate were used.

\section{Extraction}

The extraction was done by immersing $50 \mathrm{~g}$ of simplicia with $500 \mathrm{ml}$ of $96 \%$ ethanol for $24 \mathrm{~h}$ and then replaced with a new solvent with the same volume. Solvent replacement is done 3 times. The obtained liquid extracts were collected and then evaporated with a rotary evaporator, 
and the residue was dried in the oven until a viscous extract was obtained.

\section{Fractionations}

$3 \mathrm{~g}$ ethanolic extract of mistletoe leaves was dissolved in $10 \mathrm{ml}$ of ethanol and $20 \mathrm{ml}$ of sterile distilled water. Then partitioned with $30 \mathrm{ml}$ of solvent $\mathrm{n}$-hexane in separating funnel for 6 times, and then the n-hexane fraction was collected. The residue was partitioned with an ethyl acetate solvent with the same volume. Thereafter, each ethyl acetate fraction, water fraction, and n-hexane fraction were concentrated with a rotary evaporator [11].

\section{Phytochemical screening}

Fractions of water, ethyl acetate, and n-hexane were tested for phytochemical screening; there are alkaloids, flavonoids, saponins, terpenoids, and polyphenols [12].

\section{Determination of total phenolic content (TPC)}

TPC was measured using the method based on Saiah et al. [13] with some modifications. Each sample of $20 \mathrm{mg}$ was dissolved in $10 \mathrm{ml}$ of methanol, then diluted to a concentration of $100 \mu \mathrm{g} / \mathrm{ml}$. GAs are used as the standard. A total of $0.15 \mathrm{~mL}$ of the test solution (fraction or GA) was added with $0.75 \mathrm{ml}$ of the Folin-Ciocalteu reagent. The mixture was incubated for $6 \mathrm{~min}$, then $0.60 \mathrm{ml}$ sodium carbonate added to it. The mixture was incubated for $30 \mathrm{~min}$. After that, the absorption was measured using ultraviolet (UV)-visible spectrophotometer at $737 \mathrm{~nm}$. TPC test results are shown in mg GAs equivalent (GAE)/g fraction.

\section{Determination of antioxidant activity (DDPH method)}

Evaluation of antioxidant activity was done based on Molyneux [14,15] with some modifications. Each sample of $20 \mathrm{mg}$ was dissolved in methanol up to the boundary marker, then diluted until a series of concentrations were obtained. Vitamin $\mathrm{C}$ is used as a positive control. Then, as much as $0.3 \mathrm{ml}$ the test solution was reacted with $1.2 \mathrm{ml} \mathrm{DPPH}$. After incubation for $30 \mathrm{~min}$, the absorption was measured using UVvisible spectrophotometer at $515 \mathrm{~nm}$. The value of $\mathrm{IC}_{50}$ is then calculated.

\section{Statistical analysis}

Data were obtained from the antioxidant activity and TPC measurement statistically tested using one-way ANOVA followed by LSD as post hoc. The difference is considered significant if $\mathrm{p} \leq 0.01$ with a confidence level of $99 \%$. The correlation test between antioxidant activity and TPC was performed. Correlation test is done using Pearson correlation. Data are considered to correlate significantly if $\mathrm{p} \leq 0.05$.

\section{RESULTS}

\section{Extraction and fractionations}

The yield of the extract was calculated based on the ratio of the final weight (weight of the viscous extract) with the initial weight (the weight of the simplicia powder) [16]. The weight of the extract was $9.51 \mathrm{~g}$ so that the yield of the extract was $19.02 \%$. Table 1 shows the differences in percentage yield for each fraction. Based on the results of fraction yield, the n-hexane solvent has the highest extractive capability while the water solvent is the solvent with the lowest extractive ability.

\section{Phytochemical screening}

Table 2 shows the result of phytochemical screening of each fraction. Water fraction contains saponin and polyphenols. Ethyl acetate fraction contains alkaloids, flavonoids, saponins, terpenoids, and polyphenols. $\mathrm{N}$-hexane fraction only contains alkaloids and terpenoids.

\section{Determination of TPC}

TPC measurement was done using standard calibration curve that obtained regression equation to be able to count TPC at the fraction. The equation obtained for TPC measurement was $\mathrm{y}=0.094 \mathrm{x}+0.037$ with coefficient correlation (R) 0.998. TPC measurement results can be shown in Table 3. TPC from highest value to lowest is ethyl acetate fraction, $\mathrm{n}$-hexane fraction, and water fraction that significant difference $(\mathrm{p}<0.01)$.

\section{Determination of antioxidant activity}

Each fraction and Vitamin C antioxidant activity results as shown in Table 4. Positive control Vitamin C has $\mathrm{IC}_{50}$ value of $3.46 \pm 0.45 \mu \mathrm{g} / \mathrm{ml}$. $\mathrm{The}_{\mathrm{IC}} \mathrm{C}_{50}$ values of fractions from the highest to the lowest one are the ethyl acetate fraction, the n-hexane fraction, and the water fraction. These results have a significant difference from one another $(p<0.01)$.

\section{Statistical analysis}

Pearson correlation results between TPC and $\mathrm{IC}_{50}$ shown the negative correlation. It means that the greater the phenol content, the lower the $\mathrm{IC}_{50}$ value, or the better antioxidant activity. The value of significance shows that between TPC and IC ${ }_{50}$ value there is a significant correlation at $\mathrm{p}<0.05$.

\section{DISCUSSION}

Based on the percentage of yield, the fraction of n-hexane solvent has the highest extractive capability while the water solvent is the solvent with the lowest extractive capability. This result shows that the nonpolar secondary metabolite in the sample was more than those of the polar metabolite compound [17].

The measurement of antioxidant activity showed that fraction of ethyl acetate has the highest activity with $\mathrm{IC}_{50}$ value was $7.08 \pm 0.39 \mu \mathrm{g} / \mathrm{ml}$, then the fraction of n-hexane with $\mathrm{IC}_{50} 10.90 \pm 1.05 \mu \mathrm{g} / \mathrm{ml}$ and the lowest is water fraction with $\mathrm{IC}_{50}$, i.e. $29.46 \pm 0.99 \mu \mathrm{g} / \mathrm{ml}$. When all three fractions were compared with positive controls of Vitamin C, the $\mathrm{IC}_{50}$ of Vitamin $\mathrm{C}$ was smaller than the $\mathrm{IC}_{50}$ of the three fractions. This is because Vitamin C as known as ascorbic acid is a pure compound that was shown to have antioxidant activity when compared to the fraction that comprises various components.

Table 1: The percentage yield of $D$. pentandra (L.) Miq. fractions

\begin{tabular}{ll}
\hline Sample & Percentage yield (\%) \\
\hline n-hexane fraction & 26.67 \\
Ethyl acetate fraction & 10.22 \\
Water fraction & 12.22 \\
\hline D. pentandra: Dendrophthoe pentandra &
\end{tabular}

Table 2: Phytochemical screening of $D$. pentandra (L.) Miq. fractions

\begin{tabular}{llll}
\hline Secondary metabolite & Water & Ethyl acetate & n-hexane \\
\hline Alkaloids & - & + & + \\
Flavonoids & - & + & - \\
Saponins & + & + & - \\
Terpenoids & - & - & + \\
Polyphenols & + & + & - \\
\hline
\end{tabular}

+: Detected, -: Not detected. D. pentandra: Dendrophthoe pentandra

Table 3: TPC

\begin{tabular}{ll}
\hline Sample & TPC $(\mathbf{m g}$ GAE $/ \mathbf{g}$ fraction) \pm RSD (\%) \\
\hline Ethyl acetate fraction & $67.40 \pm 0.82$ \\
N-hexane fraction & $21.35 \pm 1.86$ \\
Water fraction & $9.42 \pm 1.16$ \\
\hline
\end{tabular}

$(\mathrm{n}=3$ ) (average \pm RSD [\%]), * mg GAE/g: mg gallic acid equivalent per gram.

TPC: Total phenolic content, RSD: Relative standard deviation

Table 4: Antioxidant activity

\begin{tabular}{ll}
\hline Sample & IC $_{\mathbf{5 0}}(\boldsymbol{\mu g} / \mathbf{m l})$ \\
\hline Vitamin C & $3.46 \pm 0.45$ \\
Ethyl acetate fraction & $7.08 \pm 0.39$ \\
n-hexane fraction & $10.90 \pm 1.05$ \\
Water fraction & $29.46 \pm 0.99$ \\
\hline (n=3) (ava
\end{tabular}


The high antioxidant activity of ethyl acetate fraction was suspected due to its secondary metabolite compounds that have more effect in antioxidant activity and it more dissolved in ethyl acetate than n-hexane or water such as flavonoids, tannins, quinones, and steroids [8]. This result is suitable with the previous studies by Das et al. [18] comparing antioxidant activity in ethanolic extracts, chloroform fractions, ethyl acetate fractions, and polar fractions of Crescentia cujete leaves and stems. The results showed that the fraction of ethyl acetate in both leaves and stalk has the smallest $\mathrm{IC}_{50}$ value.

The next highest antioxidant activity was the fraction of $n$-hexane with $\mathrm{IC}_{50} 10.90 \pm 1.05 \mu \mathrm{g} / \mathrm{ml}$. Secondary metabolites that are suspected which provide antioxidant activity are terpenoids, steroids, and flavonoids. Previous researches by Hanif et al. [19] mentions that n-hexane fraction in the same mistletoe species but grow in different hosts contain steroids, terpenoids, and flavonoids. Although the percentage yield value of $n$-hexane fraction was more than the other fractions, the antioxidant activity of the n-hexane fraction was weaker than the ethyl acetate fraction. This was thought to be caused by the presence of proteins, fats, and other compounds dissolved in non-polar solvents which blocking the free radical scavenging process [20]. However, the antioxidant potential of n-hexane fraction was greater than the water fraction. The presence of non-polar compounds that also have antioxidant activity in large numbers was possible to be the reason.

The lowest antioxidant potency was water fraction with $\mathrm{IC}_{50}$ $29.46 \pm 0.99 \mu \mathrm{g} / \mathrm{ml}$ likely due to the compound which is extracted less in the water solvent while most of the flavonoids and other phenol compounds dissolve more in the ethyl acetate solvent. In addition, it was possible that some of the secondary metabolites extracted in water solvents were secondary metabolites that have no antioxidant activity, so the extract using water solvents has a low antioxidation activity.

The highest to the lowest of the total phenol content was ethyl acetate fraction, n-hexane fraction, and the water fraction. The high of TPC in the ethyl acetate fraction was presumed in the presence of polyphenols having the same molecular weight as the ethyl acetate solvent such as tannins and flavanols [21]. The higher of total phenol compound at the n-hexane fraction compared with the water fraction is possible because of the low-polarity phenolic component of the soluble extract tends to dissolve in non-polar solvents [22] while most of the semi-polar phenolic compounds are more soluble in ethyl acetate than in water solvents.

Correlation test between TPC and antioxidant activity ( $\mathrm{IC}_{50}$ ) obtained correlation coefficient (r) -0.774 and (r2) 0.59908. A negative correlation indicates that the greater the total phenol content, the lower $\mathrm{IC}_{50}$ value, or the higher antioxidant activity. It means that $59.908 \%$ of antioxidant activity is contributed by phenolic content. According to Sarwono [23], a significant correlation is indicated by a value of $\mathrm{p}<0.05$. Based on Pearson's statistical test, the significance value obtained 0.014 ( $p>0.05$ ) showed that TPC with antioxidant activity $\left(\mathrm{IC}_{50}\right)$ was significantly correlated. This is suitable with previous research which states that there was a strong correlation between the content of phenol and antioxidant activity. Rohman et al. [24] reported the TPC of red fruit had a strong correlation to antioxidant activity with a correlation value of $64.5 \%$.

\section{CONCLUSION}

The highest antioxidant activity is owned by the fraction of ethyl acetate with $\mathrm{IC}_{50}$ that was $7.08 \pm 0.39 \mu \mathrm{g} / \mathrm{ml}$, then the fraction of n-hexane with $\mathrm{IC}_{50}$ is $10.90 \pm 1.05 \mu \mathrm{g} / \mathrm{ml}$ and the lowest was water fraction with $\mathrm{IC}_{50} 29.46 \pm 0.99$ $\mu \mathrm{g} / \mathrm{ml}$. The results of each sample have a significant difference to each other. The highest TPC was found in the ethyl acetate fraction with $67.4 \pm 0.82 \mathrm{mg}$ $\mathrm{GAE} / \mathrm{g}$ fraction then followed by the fraction of $\mathrm{n}$-hexane $(21.35 \pm 1.86 \mathrm{mg}$ $\mathrm{GAE} / \mathrm{g}$ fraction) and water fraction $(9.42 \pm 1.16 \mathrm{mg} \mathrm{GAE} / \mathrm{g}$ fraction). The correlation between total phenol content and antioxidant activity $\left(\mathrm{IC}_{50}\right.$ ) has $\mathrm{R}$ value -0.774 . There was a significant correlation between TPC and antioxidant activity based on their significance value $(\mathrm{p}<0.05)$.

\section{AUTHORS' CONTRIBUTIONS}

All the authors give the same contributions to this research.

\section{CONFLICTS OF INTEREST}

The authors declared that there are no conflicts of interest.

\section{REFERENCES}

1. Halliwell B, Gutteridge JM. Free Radical in Biology and Medicine. New York: Oxford University Press; 2000.

2. Prior RL, Wu X, Schaich K. Standardized methods for the determination of antioxidant capacity and phenolics in foods and dietary supplements. J Agric Food Chem 2005;53:4290-303.

3. Vicas SI, Rugina D, Socaciu C. Phytochemicals as Nutraceuticalsglobal Approaches to their Role in Nutrition and Health. China: Intech; 2012.

4. Ojowole JA, Adewole SO. Hypoglycaemic and hypotensive effects of globimetula cupulata (DC) van tieghem (Loranthaceae) aqueous leaf extract in rats. Cardiovasc J South Afr 2007;18:9-15.

5. Adler LS. Host effect on herbivory and pollination in a hemiparasitic plant. Ecol Soc Am 2002;8:2700-10.

6. Charoensin S. Antioxidant and anticancer activities of Moringa oleifera leaves. J Med Plant Res 2014:8:318-25.

7. Anwar F, Latif S, Ashraf M, Gilani AH. Moringa oleifera: A food plant with multiple medicinal uses. Phytother Res 2007;21:17-25.

8. Fajriah S, Darmawan A, Sundowo A, Artanti N. Isolasi senyawa antioksidan dan ekstrak etil asetat daun benalu Dendrophthoe pentandra L.Miq yang tumbuh pada inang lobi-lobi. J Kimia Indonesia 2007;2:17-20.

9. Fitrilia T, Bintang M, Safithri M. Phytochemical screening and antioxidant activity of clove mistletoe leaf extracts (Dendrophthoe pentandra (L.) Miq.) IOSR J Pharm 2015;5:13-8.

10. Artanti N, Firmansyah T, Darmawan A. Bioactivies evaluation of Indonesian mistletos (Dendrophthoe pentandra (L.) Miq.) leaves extracts. J Appl Pharm Sci 2012;2:24-7.

11. Ritna A, Anam S, Khumaidi, A. Identifikasi senyawa flavonoid pada fraksi etil asetat benalu batu (Begonia Sp.) asal kabupaten morowali utara. J Pharm 2016;2:83-9.

12. Departemen Kesehatan RI. Materia Medika Indonesia Jilid V. Jakarta: Direktorat Pengawasan Obat dan Makanan; 1989. p. 116.

13. Saiah H, Allem R, Kebir FZ. Antioxidnt and antibacterial activities of six algerian medicinal plants. Int J Pharm Pharm Sci 2016;8:368-74.

14. Molyneux P. The use of stable free radical diphenylpicryl hydrazyl (DPPH) for estimating antioxidant activity. Songklanakarin J Sci Technol 2004;26:211-9.

15. Fidrianny I, Nadia E, Ruslan K. In vitro antioxidant activities, total flavonoid, phenolic and carotenoid content from various extracts of four species Asteraceae herb. Int J Pharm Pharm Sci 2015;7:192-7.

16. Sani RN, Nisa FC, Andriani RD, Maligan JM. Analisis rendemen dan skrining fitokimia ekstrak etanol mikroalga laut Tetraselmis chuii. J Pangan Agroindustri 2013;2:121-6.

17. Lisdawati V, Kardono BS. Antioxidant activity of various extract of mesocarp and seed of Phaleria macrocarpa. Media of Health R\&D XVI. 2006;4

18. Das N, Islam E, Jahan N, Islam MS, Khan A, Islam MR, et al. Antioxidant activities of ethanol extracts and fractions of crescentia cujete leaves and stem bark and the involvement of phenolic compounds. BMC Complementary Altern Med 2014;14:45.

19. Hanif RM, Kartika R, Simanjuntak P. Isolasi dan identifikasi senyawa kimia dari ekstrak n-heksan batang benalu tanaman jeruk (Dendrophthoe pentandra (L.) Miq). J Kimia Mulawarman 2016;14:1.

20. Pine SH. Kimia Organik. Terbitan Keempat. Bandung: Penerbit ITB; 1988.

21. NurAM, Astawan M. Antioxidant capacity of bawang dayak (Eleutherine palmifolia) in Fresh, Simplisia and Chips from on Nonpolar, Semipolar and Polar Solvents. Bogor: Institut Pertanian Bogor; 2011.

22. Bangol E, Momuat LI, Abidjulu J. Aktivitas antioksidan ekstrak etanol dan $\mathrm{n}$-Heksana dari rumput santa maria (Artemisia vulgaris L.) pada minyak ikan. J Ilmiah Sains 2014;14:129-35.

23. Sarwono P. Ilmu Kebidanan. Jakarta: Yayasan Bina Kusuma; 2009.

24. Rohman A, Riyanto S, Yuniarti N, Saputra WR, Utami R, Mulatsih W. Antioxidant activity, total phenolic, and total flavonoid of extracts and fractions of red fruit (Pandanus conoidens Lam). Int Food Res J 2010;17:97-106. 